\title{
The human EZH2 gene: genomic organisation and revised mapping in $7 q 35$ within the critical region for malignant myeloid disorders
}

\author{
Carlos Cardoso $^{1}$, Cecile Mignon ${ }^{1}$, Gilles Hetet ${ }^{2}$, Bernard Grandchamps ${ }^{2}$, Michel Fontes $^{1}$ \\ and Laurence Colleaux ${ }^{1}$
}

\author{
${ }^{1}$ INSERM U491, Faculté de M édecine de la Timone, Marseille; ${ }^{2}$ INSERM U409 and Centre de Recherche Claude \\ Bernard, Faculté de M édecine Xavier Bichat, Paris, France
}

The EZH2 gene is a homolog of the Drosophila Polycomb group (PcG) gene enhancer of zest, a crucial regulator of homeotic gene expression. Several lines of evidence suggest a critical role for the EZH2 protein during normal and perturbed development of the haematopoietic and central nervous systems. Indeed, the EZH2 protein has been shown to associate with the Vav proto-oncoprotein and with the XNP protein, the product of a mental retardation gene. The EZH2 gene was previously reported to be located on chromosome 21q22 and was proposed as a candidate gene for some characteristics of the Down syndrome phenotype. We report here the genomic structure and fine mapping of the EZH2 gene. We demonstrate that the functional gene actually maps to chromosome 7q35 and that the sequence previously isolated from a chromosome 21 cosmid corresponds to a pseudogene. Finally, the nature of the EZH2 protein and its mapping to the critical region for malignant myeloid disorders lead us to propose the EZH2 gene is involved in the pathogenesis of 7q35-q36 aberrations in myeloid leukaemia. European Journal of Human Genetics (2000) 8, 174-180.

Keywords: EZH2; genomic structure; 7q35; pseudogene; malignant myeloid disorders

\section{Introduction}

The Polycomb group (Pc-G) and the Trithorax group (trxG) genes were originally identified in Drosophila as being responsible for the maintenance of expression boundaries of homeotic genes. ${ }^{1}$ Their gene products are thought to act in multiprotein complexes at the level of chromatin structure, where PcG proteins maintain inactive homeotic genes in repressed state whereas trxG proteins ensure maintenance of the active state. Currently, 11PcG genes have been isolated ${ }^{2}$ and among these, enhancer of zest $(E(z))$ seems to play a central role. Firstly, it is one of the very few PcG genes conserved in lower eukaryotes ${ }^{3}$ and, secondly, according to the phenotype analysis of loss-of-function mutations, $E(Z)$ appears to be a pleiotropic gene with function in chromatin architecture, gene regulation and growth control.

Correspondence: Dr Laurence Colleaux, INSERM U491, Faculté de

Médecine de la Timone, 27 Bd Jean Moulin, 13005 Marseille, France. Tel: +33491784477; Fax: +334918043 19; E-mail:

colleaux@medecine.univ-mrs.fr

Received 4 June 1999; revised 9 August 1999; accepted 6 October 1999
Mammalian homologs of both PcG and trxG genes have also been identified and a remarkable degree of functional conservation have been demonstrated by different groups. ${ }^{4,5}$ The human $E(Z)$ homolog $E Z H 2$ was initially isolated in a search for proteins that associate specifically with Vav, a human proto-oncogene product involved in lymphocyte development and activation. ${ }^{6}$ This interaction suggests involvement of the EZH 2 protein in signal-dependent T-cell proliferation. The same gene sequence was also identified in an exon-trapping experiment performed with cosmid DNA from a human chromosome21 specific library in order to isolate genes from the so-called Down syndrome critical region. ${ }^{7}$ The latter data led the authors to map the EZH 2 gene to human chromosome21q22.2 and to suggest that overexpression of this gene in trisomy 21 may be associated with some of the clinical features of Down syndrome. More recently, we reported that the EZH2 protein is also involved in an interaction with the XNP protein, ${ }^{8}$ a gene involved in several X-linked mental retardation conditions, sometimes associated with $\alpha$-thalassaemia, an association which may 
reflect an important role in central nervous system development and haematopoietic development.

To elucidate the potential role of the $\mathrm{EZH} 2$ gene in either Down syndrome or in the syndrome associated with the deletion of $21 q 22$, we decided to determine the genomic structure of the $\mathrm{EZH} 2$ gene. In this report we demonstrate that the human EZH2 gene is divided into 20 exons. More importantly, we found that EZH 2 maps to chromosome 7q35 and that the EZH2 copy previously assigned to chromosome 21 corresponds to a pseudogene.

\section{Materials and methods In silico analysis}

Blast searches were conducted either at the Washington University Genome Sequencing Center (http://genome.wustl.edu/gsc/blast/blast - servers) against a human genomic database (St Louis project only) or at the National Center for Biotechnology Information (www.ncbi.nlm.nih.gov/cgi-bin/ BLAST/) against the non-redundant Genban$\mathrm{k}+\mathrm{EMBL}+\mathrm{DDBJ}+\mathrm{PDB}$ sequences. The EZH2 sequence used for this purpose was the one corresponding to Genbank entry U61145. Sequence alignments were performed using the TBLASTN program ${ }^{9}$ (version 2.0.8, Jan-05-1999).

\section{Southern blot analysis}

Six $\mu \mathrm{g}$ of total human DNA and $1 \mu \mathrm{g}$ of YAC DNA were digested with Pstl. The DNAs were transferred to a nylon membrane using standard methods. ${ }^{10}$ Hybridisation was performed at $65^{\circ} \mathrm{C}$ overnight. The probe used to detect the $\mathrm{EZH} 2$ gene was a $2 \mathrm{~kb}$ long PCR product obtained by amplifying EZH2 CDNA using primers $\mathrm{EZH}_{2}(1) 5^{\prime} \mathrm{CAG}$ GATGGTACTTTCATTG3' and EZH ${ }_{2}(4)$ 5'GCCTTCTCACCAGCTGCAA $3^{\prime}$ corresponding respectively to position 508-566 and 2490-2509 of the cDNA sequence.

\section{Fluorescence in situ hybridisation}

Metaphase spreads were prepared from phytohaemagglutinin-stimulated human lymphocytes, cultured at $37^{\circ} \mathrm{C}$ for $96 \mathrm{~h}$ 5-bromodeoxyuridine was added for the final $7 \mathrm{~h}$ of culture $(60 \mu \mathrm{g} / \mathrm{ml}$ of medium) to ensure a chromosomal R-banding of good quality. The $803 \mathrm{~g} 1 \mathrm{YAC}$ clone, containing an insert of $1000 \mathrm{~kb}$, was biotinylated by random priming with biotin-16-dUTP, as outlined by the Life Technologies (Bio Prime Kit) protocol. Hybridisation to chromosome spreads was performed using a standard protocol. ${ }^{11}$ For each slide, $400 \mathrm{ng}$ of biotinylated DNA was used. The hybridised probe was detected by means of fluorescence isothiocyanateconjugated avidin. Chromosomes were counterstained and $\mathrm{R}$-banded with propidium iodide diluted in antifade solution $\mathrm{pH} 11.0$ as previously described. ${ }^{12}$

\section{RT-PCR and expression analysis}

RNA was extracted from the various sources using the QuickPrep mRNA purification kit, according to the instruc- tions of the manufacturer (Pharmacia, Courtabeuf, France). Reverse transcription of $500 \mathrm{ng}$ of mRNA was performed in $50 \mu \mathrm{l}$ of $1 \mathrm{X}$ Superscript reaction buffer (Gibco BRL, Life Technologies, Cergy Pontoise, France) containing $3 \mathrm{ng}$ of $(\mathrm{dN})_{6} / \mu \mathrm{l}, 40$ units of Rnasin (Promega), $1 \mathrm{~mm} \mathrm{dNTP}$, and 200 units of Superscript II reverse transcriptase. A 1/10 volume of template was used in $50 \mu \mathrm{l}$ of PCR mixture, containing $0.2 \mathrm{~mm}$ deoxynucleosides triphosphates, $1.5 \mathrm{~mm} \mathrm{MgCl}_{2}$ and $1 \mathrm{U}$ of Taq polymerase. The cycling program was $4 \mathrm{~min}$ at $96^{\circ} \mathrm{C}$, followed by 35 cycles of $40 \mathrm{~s}$ at $94^{\circ} \mathrm{C}, 40 \mathrm{~s}$ at $58^{\circ} \mathrm{C}$ and $1 \mathrm{~min}$ at $72^{\circ} \mathrm{C}$, and a final extension of $5 \mathrm{~min}$ at $72^{\circ} \mathrm{C}$. PCR amplifications were performed with the primers $\mathrm{EZH}_{2}(4)$ and $\mathrm{EZH}_{2}$ (8): 5'TACATGTGCAGCTTTCTGTTC 3' or $\mathrm{EZH}_{2}(9)$ : 5'AGCTAAGGCAGCTGTITCAGA 3' corresponding respectively to nucleotides 2067-2088 and 2352-2372 of the EZH2 CDNA sequence. $25 \mu \mathrm{l}$ of PCR products were then digested by the enzyme Alu I for $2 \mathrm{~h}$ at $37^{\circ} \mathrm{C}$. Digested and undigested PCR products were loaded on a $4 \%$ gel and visualised after ethidium bromide staining.

\section{Patients}

Paired samples were obtained from 20 patients with myeloid disorders (de novo acute myeloid leukaemia (AML) $n=11$; acute transformation of myelodysplastic syndrome (MDS), $n=9$ ). Blast cells were isolated at the time of diagnosis either from blood or from bone marrow samples using a ficoll (Life Technology, Cergy Pontoise, France) gradient. ${ }^{13}$ T-lymphocytes were purified from blood obtained in remission using Dynal beads (Dynal, Compiègne, France). ${ }^{14}$

\section{Genotyping studies}

Four si mple tandem repeat (STR) markers were used: D7S688, D7S505, D7S642, D7S483. Primers sequences and percentages of heterozygosity were obtained from the Genome Data Base (http://gdb.infobiogen .fr)

Polymerase chain reaction (PCR) was performed with a 5 'fluorescein-labelled upstream primer. Five microlitres of cellular lysate was amplified in a total volume of $25 \mu \mathrm{l}$ containing $10 \mathrm{pmol}$ of $5^{\prime}$ and $3^{\prime}$ primers, $0.2 \mathrm{~mm}$ dNTPs, $1.5 \mathrm{~mm} \mathrm{MgCl}_{2}, 50 \mathrm{~mm} \mathrm{KCl}, 10 \mathrm{~mm}$ Tris- $\mathrm{HCl}(\mathrm{pH} 8.3)$ and $0.2 \mathrm{U}$ of Taq polymerase (Gibco, Life Technologies, Cergy Pontoise, France). Taq polymerase was added after a denaturation step of $5 \mathrm{~min}$ at $96^{\circ} \mathrm{C}$. The PCR cycling parameters were $20 \mathrm{~s}$ at $95^{\circ} \mathrm{C}, 20 \mathrm{~s}$ at $50^{\circ} \mathrm{C}$, and $5 \mathrm{~s}$ at $72^{\circ} \mathrm{C}$ for 30 cycles performed in a UNO-Thermoblock (Biometra, Göttingen, Germany).

After denaturation, the PCR products were analysed using a fluorescent automated laser DNA sequencer (ALF; Pharmacia LKB Biotechnology, Uppsala, Sweden). Electrophoresis was achieved on a $6 \%$ long-ranger gel containing $8 \mathrm{~mol} / \mathrm{L}$ urea in a $0.6 \mathrm{X}$ Tris-borate-EDTA buffer. The PCR products obtained from the blasts cells were compared with those obtained from normal cells of the same patient obtained during remission. Areas under the curve of the peaks were determined using the software Fragment $M$ anager (Pharmacia). If $A 1$ and $A 2$ represent the two alleles in a heterozygous 
patient, the ratio of signal $\mathrm{A} 1 / \mathrm{A} 2$ was calculated for normal and blast cell samples. The relative copy number of alleles in blast cells samples was then calculated as $R=[(A 1 / A 2)$ blasts]/[(A1/A2) remission ]. For each patient results obtained with blast cell DNA were compared with corresponding matched normal cells. A loss of heterozygosity ( $\mathrm{LOH}$ ) usually appears as a decrease rather than a total disappearance of the lost allele because of the persistence of $1-30 \%$ normal marrow cells in samples of blast cells. When both alleles were present in the blast cell population, the allelic ration was close to 1 . Samples were considered to have undergone LOH when ratios were less than $0.30 .^{15}$

\section{Results}

\section{Genomic organisation and chromosomal localisation of the EZH2 gene}

To characterise a genomic clone containing the $\mathrm{EZH} 2$ gene, we performed TBLASTN searches using the EZH2 protein sequence against the St Louis genomic sequences database. We have identified a PAC clone (dJ1151M05, accession
No. AC 006323$)$ containing regions with $100 \%$ nucleotide identity to the entire EZH 2 cDNA sequence. We conclude that this PAC covers the EZH2 structural genelocus. Genomic organisation of the EZH2 gene was then determined by sequence alignment between the cDNA sequence and the sequence of clone dJ1151M O5. As indicated in Figure $1 \mathrm{~A}$ and Table1, the EZH2 gene spans approximately $40 \mathrm{~kb}$ and is composed of 20 exons. The exons range in size from 41 to $323 \mathrm{bp}$ and the introns from 0.15 to $17.7 \mathrm{~kb}$. Sequences at the intron-exon junctions are given in Table1. They all follow the gt/ag rule $\mathrm{e}^{16}$ and score highly in terms of the derived consensus sequences at these sites. ${ }^{17}$

Analysis of the PAC dJ $1151 \mathrm{MO} 5$ sequence indicated that it also contained markers D7S688 (within EZH2 intron 2), D7S2419 and the gene Hs-cul-1. ${ }^{18}$ These data suggested that the gene mapped to chromosome7q35 rather than to chromosome 21 as previously assigned. To verify by Southern blot and FISH mapping the location of the EZH 2 gene, a YAC clone $(803 \mathrm{~g} 1)$ containing marker D7S688 was identify by searching the CEPH-Généthon database (www.cephb.fr/cgibin). A Southern blot containing human DNA or DNA from

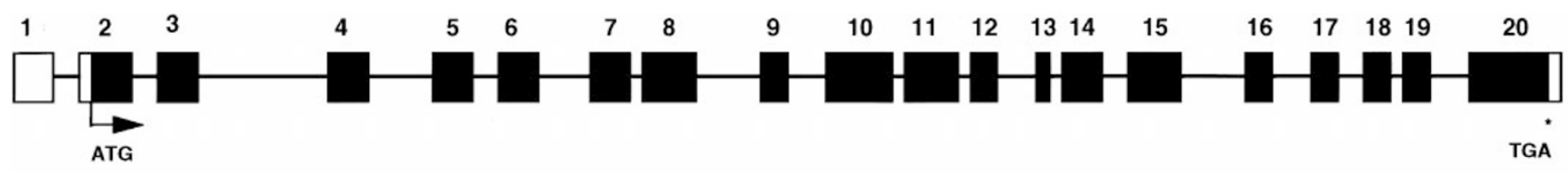

A.

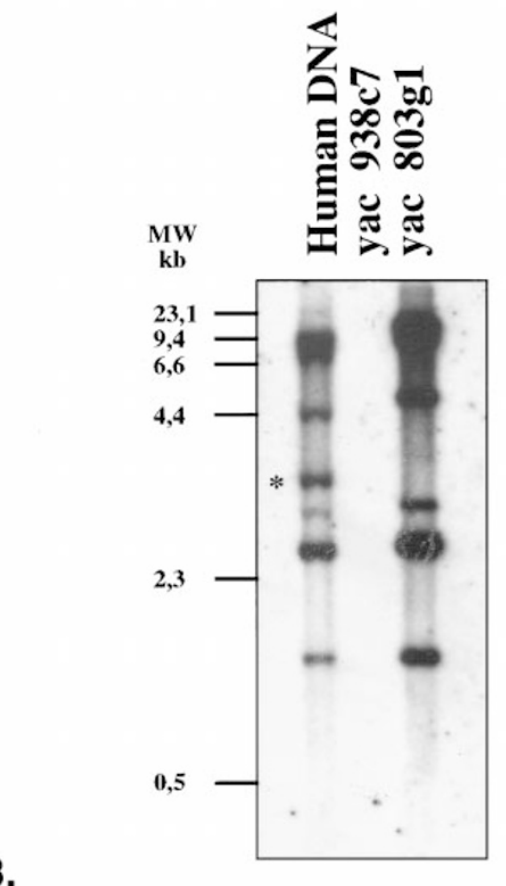

B.

Figure 1 A Schematic illustration of the genomic structure of the EZH2 gene. The human EZH2 gene contains 20 exons (boxes). The open reading frame (black boxes) is distributed over 19 exons. The positions of the initiation (ATG) and termination (TGA) codons are indicated. B Comparative Southern blot analysis of human genomic DNA and DNA from YAC $803 \mathrm{~g} 1$. Pst I digests were size-fractionated on a 1\% agarose gel and analysed as described under Materials and methods. YAC 938 c 7, located elsewhere on chromosome 7, was used as a control. 
Table 1 Intron/exon boundaries of the human EZH2 gene. Exonic sequences are in upper case and intronic sequences in lower case. The 5'gt and 3'ag ends of introns are indicated in bold. ND: not determined

\begin{tabular}{|c|c|c|c|c|}
\hline Exon & $\begin{array}{l}\text { Size } \\
\text { (bp) }\end{array}$ & 5' splice donor & $\begin{array}{l}\text { Intron } \\
\text { size (bp) }\end{array}$ & 3' splice acceptor \\
\hline 1 & ND & ND & ND & cttttag ААТАAT \\
\hline 2 & 124 & GTAAAGgt ataatt & 577 & ttaaag AGTATG \\
\hline 3 & 128 & AGGGAGgt tggtt & 13720 & gttttag TGTTCG \\
\hline 4 & 117 & TTTATGgt atgta & 2785 & ttttag GTGGAA \\
\hline 5 & 121 & ATAGAGgt gagcC & 846 & gtttcag AATGTG \\
\hline 6 & 141 & GAGATGgt atgCC & 1473 & tgtttag ATAAAG \\
\hline 7 & 103 & GGAAAAgt aagaa & 533 & atgtcag ATATAA \\
\hline 8 & 164 & TACATCgt aagtg & 6781 & tttgcag СТTTTC \\
\hline 9 & 92 & CATTTGgt aagac & 1477 & ttcgtag GAGGGA \\
\hline 10 & 242 & ССТсTGgt aagac & 484 & tttgtag AAGCAA \\
\hline 11 & 170 & AGACAGgt aaga & 443 & ttgtcag GTGTAT \\
\hline 12 & 95 & ACACCGgt gagtc & 1140 & tttgcag GTTGTG \\
\hline 13 & 41 & AAAAGGgt tagca & 466 & tactcag ACGGCT \\
\hline 14 & 126 & CAGAGTgt aagta & 776 & tctgaag GTCAAA \\
\hline 15 & 179 & AAAAAGgt gagca & 2238 & tctctag САТСТА \\
\hline 16 & 96 & GGAGAGgt aaggc & 1210 & tttttag ATTATT \\
\hline 17 & 82 & ACAATGgt atgtt & 943 & cttttag АTTTTG \\
\hline 18 & 81 & CAAAAGgt aggta & 154 & tttgcag TTATGA \\
\hline 19 & 85 & TTACAGgt tgtga & 1365 & gtttcag ATACAG \\
\hline 20 & $>323$ & & & \\
\hline
\end{tabular}

yeast cells containing this YAC was then probed with the complete EZH2 CDNA sequence. As shown in Figure 1B, the results confirm that the YAC $803 \mathrm{~g} 1$ contains the $\mathrm{EZH} 2$ gene since a total of 5DNA fragments were detected. When compared with the banding pattern obtained with human genomic DNA, an additional approximately $3.3 \mathrm{~kb}$-long Pstl fragment, absent from YAC $803 \mathrm{~g} 1$, was detected suggesting that the sequence corresponding to the probe cross-hybridises with another locus in the human genome. FISH mapping was also performed using the YAC $803 \mathrm{~g} 1$ as a probe. As observed in Figure2, this YAC is located in chromosomal band7q35. Altogether, these experiments demonstrate unambiguously that the EZH2 sequence is located in $7 q 35$.

\section{Sequence and expression analysis of the EZH2 copy located on chromosome21}

Since previously published data located the EZH2 gene on chromosome $21 q 22^{7}$ and because Southern blot analysis indicated the presence of a second sequence cross-hybridising with the EZH2 probe, we searched for the corresponding genomic sequence by performing a BLASTN search with the EZH2 CDNA sequence against all genomic sequences deposited in genbank (NCBI). This search identified two cosmid clones from chromosome21 (No.AF015726 and AJ 229042) which showed $95 \%$ nucleotide identity between a 562 bp long genomic fragment and a segment corresponding to the SET domain of EZH2 CDNA (from exon 17 to 20) (Figure $3 A$ ). However, no sequence homologous to the $5^{\prime}$ region of the EZH2 ORF was present in any cosmid analysed. In addition, careful analysis of the alignement revealed a surprising organisation. First, as shown in Figure3B,

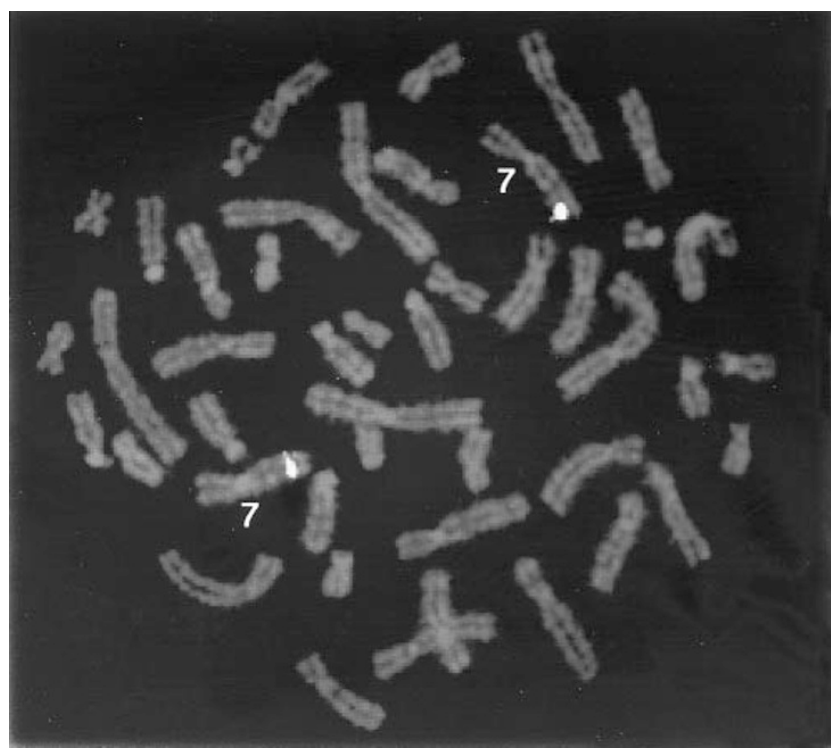

Figure 2 FISH mapping of the EZH2 gene. DNA from clone $803 \mathrm{~g} 1$ was used as a probe for FISH analysis as described under Materials and methods. A total of 30 metaphase cells were analysed, and $98 \%$ of the cells showed specific fluorescent spots on the 7q34-q35 bands of the human genome.

introns 17, 18 and 19 are absent from the chromosome 21 EZH 2 copy and secondly, the 3'UTR is found proximal to the coding sequence. This surprising organisation was confirmed by PCR analysis presented in Figure $3 C$. Indeed, primers 4 and 8 were shown to lead to the amplification of an expected $2900 \mathrm{bp}$ long product from genomic DNA (encompassing introns 17, 18 and 19) and to the synthesis of an expected 422 bp long fragment from cDNA. On the contrary primers 4 and 9 were shown to be unable to amplify any product from cDNA but led to the synthesis of an expected $482 \mathrm{bp}$ long fragment from genomic DNA. We also examine the cosmid sequence for the presence of Pstl sites around the homologous region and found that the conserved sequenced is totally contained within a 3236 bp long Pstl fragment. This result strongly suggests that the additional Pstl fragment detected in the Southern blot experiment originates in $21 q 22$.

Lastly, to ensure that the chromosome21 copy did not correspond to any expressed sequence, we took advantage of the Alul restriction site polymorphism found between both sequences: the chromosome 7 copy contains an Alul restriction site which is absent from the one in chromosome 21. A series of RT-PCR experiments followed by Alul digestion were performed and the results are shown in Figure4. They indicate that, in RNA from either 9 week-old embryo or from foetal brain, the PCR product obtained is totally digested by Alul and that no undigested product remains. No RNA originating from the chromosome21 copy can therefore be detected in these samples. Two other types of cell or tissues 
SET domain Chromo. 21 EZH2 SET domain

SET domain Chromo. 21 EZH2 SET domain
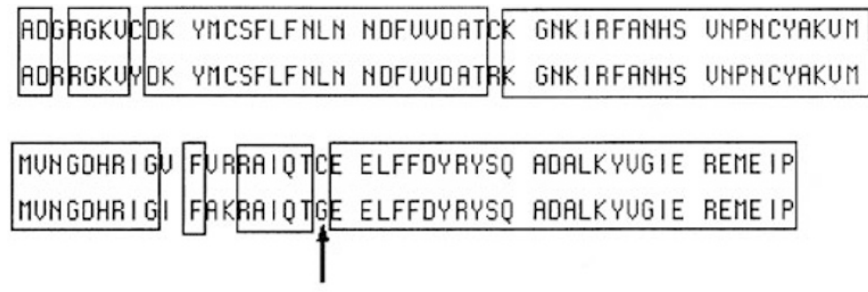

746

A

Site Alu I

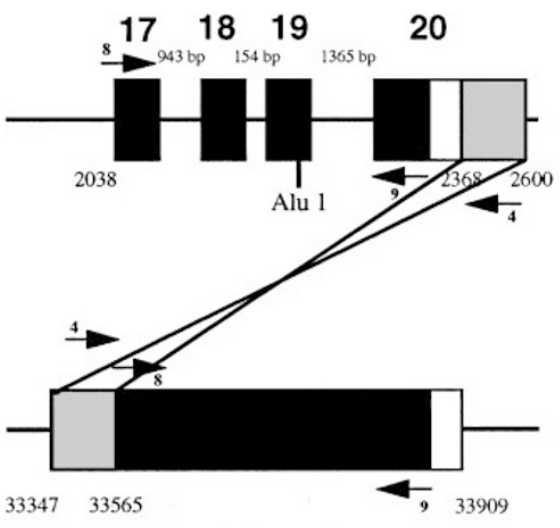

Chromosome 7 Copy

Chromosome 21 Copy

B

C

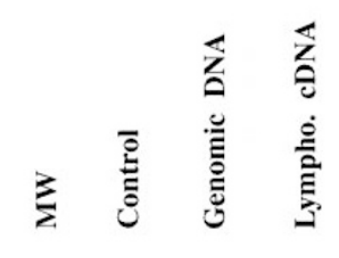

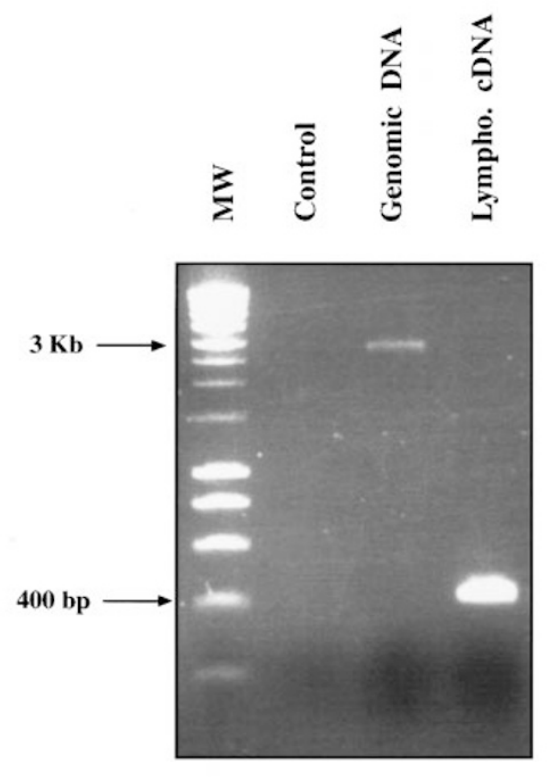

EZH2 (8) / EZH2(4)

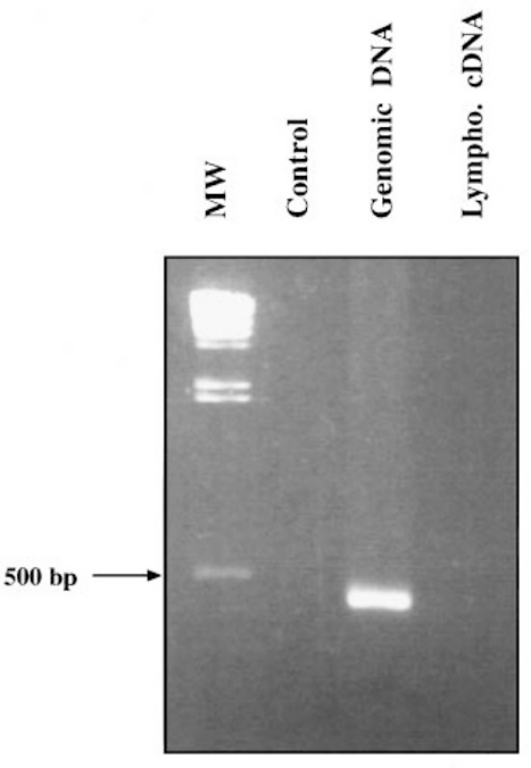

Primers

EZH2 (9) / EZH2(4)

Figure 3 A Amino acid sequence alignment between chromosome 7 and chromosome 21 genes. Common sequences are boxed and the position of the Alul restriction site which encompasses one of the divergent positions is indicated B Structural comparison of the conserved region between chromosome 7 and chromosome 21 . The schematic figure compares the structures of exon 17 to 20 from the EZH2 gene with the structure of nucleotides 33347 to 33909 from the chromosome 21 cosmid. Exons are represented by boxes. The black boxes indicate coding of the region. Primers used in RT-PCR experiments are shown as well as the position of the Alul site. The inversion of the sequence corresponding to nucleotide $2368-2600$ of the EZH2 cDNA sequence (grey box) is shown. C PCR results using primers EZH2 (8) and (4) or EZH2 (9) and (4) on human genomic DNA or human CDNA from 9-week-old embryos. A control with no DNA was also performed under the same conditions. 


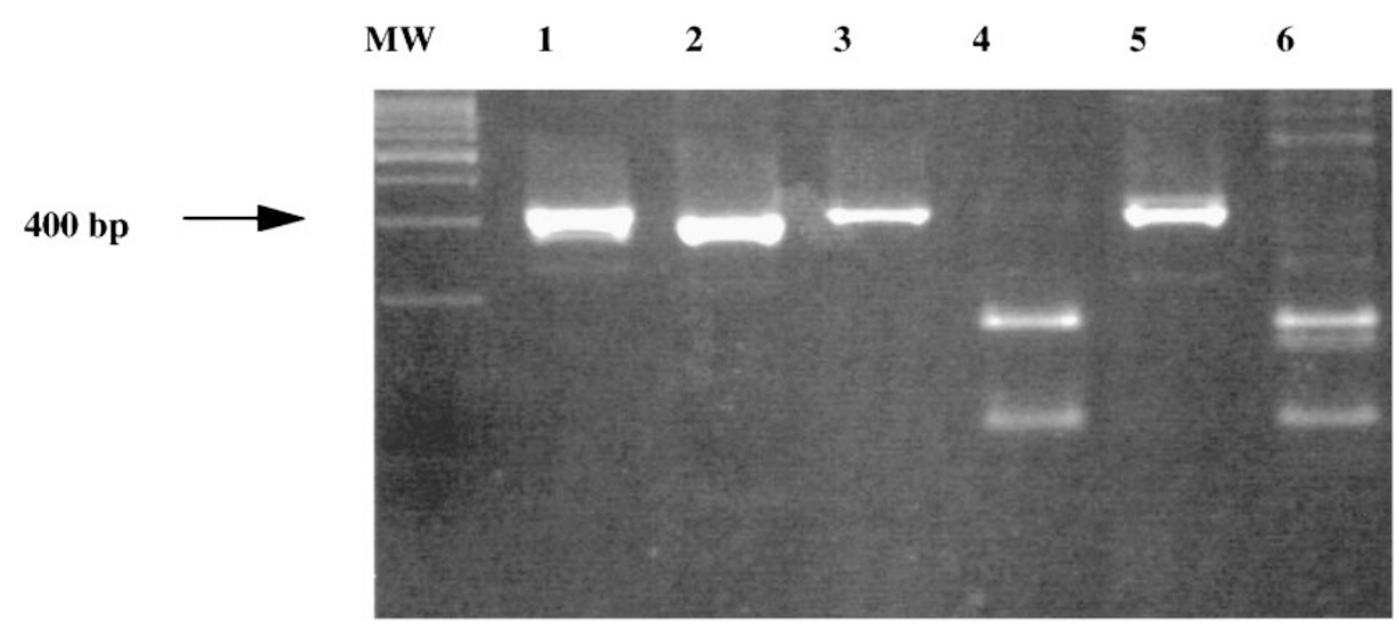

Figure 4 Expression analysis of the chromosome 7 and chromosome $21 \mathrm{EZH} 2$ sequences. RT-PCR fragments produced using primers EZH2 (8) and (9) were analysed by Alul restriction. 1: undigested human genomic DNA; 2: digested human genomic DNA; 3: undigested human embryonic cDNAs; 4: digested human embryonic CDNAs; 5: undigested human foetal brain cDNAs; 6: digested human foetal brain cDNAs.

were also tested: foetal liver and HeLa cells and gave the same results (data not shown). These data together provide strong evidence that the chromosome 21 sequence corresponds to an EZH 2 pseudogene.

\section{Localisation of the EZH2 gene within a critical region for myeloid disorders}

Since previous analysis indicated that 7q31-qter is a critical region for malignant myeloid disorders, ${ }^{19}$ patients with either acute myeloid leukaemia (AML) or myelodysplastic syndrome (MDS) were tested for deletion of the EZH 2 gene by testing the $\mathrm{LOH}$ for markers flanking the $\mathrm{EZH} 2$ gene. Our results (data not shown) indicate that the allele loss is detected in five out of 21 patients (three with de novo AML and two with acute transformation of MDS) for the four informative microsatellite markers tested, including marker D7S688 located within intron 2 of the $\mathrm{EZH} 2$ gene. This proportion is in agreement with a previous report ${ }^{9}$ and support the finding that the EZH 2 gene is located within a region that is commonly deleted in myeloid disorders.

\section{Discussion}

We have defined the multiexonic structure of the human $\mathrm{EZH} 2$ gene and determined the sequences of the exon-intron boundaries. We have also shown by cytogenetic and molecular analysis that this gene maps to the long arm of chromosome 7 at position 7q35, in a region corresponding to the polymorphic marker D7S688. Interestingly, the murine Ezh2 gene has been recently mapped to a region of mouse chr $6,{ }^{20}$ which has synteny with human chromosome $7 q 35$. Further, we found that the sequence previously isolated from chromosome21q22 corresponds to a pseudogene, ruling out the possibility that overexpression of the chromosome21 copy could be responsible for some of the clinical features of
Down syndrome. Finally, since our Southern blot analysis indicates that DNA fragments detected with a EZH 2 probe on human genomic DNA were all accounted for by the bands in YAC $803 \mathrm{~g} 1$ and cosmid AF015726, the presence of another $\mathrm{EZH} 2$-related sequence in the human genome is very unlikely.

The precise function of EZH2 is not known. However, its specific in vitro and in vivo interaction with the Vav protooncoprotein suggests involvement in haematopoietic development and signal-dependant T-cell proliferation. In addition, the EZH2 protein shares the SET domain, a domain characteristic of a family of chromatin regulators, ${ }^{21}$ with the human trithorax homolog ALL-1/HRX, another proto-oncogene that is frequently disrupted in 11 q23 translocations in acute leukaemias. ${ }^{22,23}$ Finally, studies of another vertebrate Pc-G gene, the mouse Bmi-1 gene has demonstrated that unregulated activation of this gene generates B- and T-cell lymphomas and its deletion causes severe defects in haematopoietic development, particularly in lymphopoiesis and myelopoiesis, ${ }^{24}$ providing further evidence for a specific function of Pc-G genes in haematopoiesis. In this regard, the demonstration that EZH2 maps within a region known to exhibit $\mathrm{LOH}$ in myeloid disorders is of great interest and makes it a potential candidate for being involved in these malignancies. Determination of the EZH 2 genomic structure should facilitate further investigations aiming to screen for inactivating mutations in such patients.

\section{Acknowledgements}

We are particularly indebted to Kathleen Gardiner for sharing an unpublished observation. We also thank C Schwartz for critical reading of the manuscript. This study was supported by grants from the Institut National de la Santé et de la Recherche Médicale and from the Association pour la Recherche contre le Cancer. 


\section{References}

1 Pirotta V: Chromatin complexes regulating gene expression in Drosophila. Curr Opin Genet Dev 1995; 5: 466-472.

2 Pirotta V: PcG complexes and chromatin silencing. Curr Opin Genet Dev 1997; 7: 249-258.

3 Korf I, Fan Y, Strome S: The polycomb group in Caenorhabditis elegans and maternal control of germline development. Development 1998; 125: 2469-2478.

4 Schumacher A, Magnuson T: Murine Polycomb and trithoraxgroup genes regulate homeotic pathways and beyond. Trends Genet 1997; 13: 167-170.

5 Laible G, Wolf A, Dorn R et al: Mammalian homologues of the Polycomb-group gene Enhancer of zeste mediate gene silencing in Drosophila heterochromatin and at S. cerevisiae telomeres. EMBO J 1997; 16: 3219-3232.

6 Hobert O, Jallal B, Ullrich A: Interaction of Vav with ENX-1, a putative transcriptional regulator of homeobox gene expression. Mol Cell Biol 1996; 16: 3066-3073.

7 Chen H, Rossier C, Antonorakis SE: Cloning of a human homolog of the drosophila Enhancer of zests gene $(E Z H 2)$ that maps to chromosome21q22.2. Genomics 1996; 38: 30-37.

8 Cardoso C, Timsit S, Villard L, Khrestchatisky M, Fontes M, Colleaux L: Specific interaction between the XNP/ATR-X gene product and the SET domain of the human EZH2 protein. Hum Mol Genet 1998; 7: 679-684.

9 Altschul SF, Gish W, Miller W, Myers EW, Lipman DJ: Basic local alignment search tool. J Mol Biol 1990; 215: 403-410.

10 Sambrook T, Fritsch EF, Maniatis T: M olecular Cloning: a Laboratory Manual. Cold Spring Harbor Laboratory Press: Cold Spring Harbor, NY, 1989.

11 Pinkel D, Straume T, Gray JW: Cytogenetics analysis using quantitative, high sensitivity, fluorescence hybridization. Proc Natl Acad Sci USA 1986; 83: 2934-2938.

12 Lemieux N, Dutrillaux B, Viegas-Pequignot E: A simple method for simultaneous R- or G- banding and fluorescence in situ hybridization of small single-copy gene. Cytogenet Cell Genet 1992; 59: 311-312.

13 Cave H, Gerard B, Martin E et al: Loss of heterozygosity in the chromosomal region 12p12-13 is very common in childhood acutelymphoblastic leukemia and permits the precise localization of a tumor-suppressor gene distinct from p27KIP1. Blood 1995; 86: 3869-3875.
14 El Kassar N, Hetet G, Briere J, Grandchamp B: X-chromosome inactivation in healthy females: incidence of excessive lyonization with age and comparison of assays involving DNA methylation and transcript polymorphisms. Clin Chem 1998; 44: 61-67.

15 Raynaud S, Cave $\mathrm{H}$, Baens $\mathrm{M}$ et al: The 12;21 translocation involving TEL and deletion of the other TEL allele: two frequently associated alterations found in childhood acute lymphoblastic leukemia. Blood 1996; 87: 2891-2899.

16 Breathnach R, Chambon P: Organisation and expression of eucaryotic split genes coding for proteins. Annu Rev Biochem 1981; 50: 349-383.

17 Shapiro MB, Senepathy P: RNA splice junctions of different classes of eukaryotes: sequence statistics and functional implications in gene expression. Nucleic Acids Res 1987; 15: 7155-7174.

18 Michel JJ, Xiong Y: Human CUL-1, but not other cullin family members, selectively interacts with SKP1 to form a complex with SKP2 and cyclin A. Cell Growth Differ 1998; 9: 435-449.

19 Dohner K, Brown J, Hehmann U et al: Molecular cytogenetic characterization of a critical region in bands 7q35-q36 commonly deleted in malignant myeloid disorders. Blood 1998; 92: 4031-4035.

20 Laible G, Haynes AR, Lebersorger A et al: The murine polycombgroup genes Ezh1 and Ezh2 map close to Hox gene clusters on mouse chromosome 11 and 6. Mamm Gen 1999; 10: 311-314.

21 Jenuwein T, Laible G, Dorn R, Reuter G: SET-domain proteins modulate chromatin domains in eu- and heterochromatin. Cell Mol Life Sci 1998; 54: 80-93.

22 Djabali M, Selleri L, Parry $P$ et al: A trithorax-like gene is interrupted by 11q23 translocations in acute leukemia. Nat Genet 1992; 2: 113-118.

23 Tkachuk DC, Kohler S, Cleary ML: Involvement of a homolog of Drosophila trithorax by 11q23 chromosomal translocations in acute leukemias. Cell 1992; 71: 691-700.

24 Van der Lugt NM, Domen J, Linders K et al: Posterior transformation, neurological abnormalities, and severe hematopoietic defects in mice with a targeted deletion of the bmi-1 protooncogene. Genes Dev 1994; 8: 757-769. 